Jacek SOBCZAK

Uniwersytet im. Adama Mickiewicza, Poznań

\title{
Problem uchodźców i migracji w optyce Deklaracji Haskiej z 2002 r.
}

kres „wędrówki ludów” nie zakończył się wcale we wczesnym śre-
dniowieczu. Jego renesans to wiek XX i, jak się wydaje, również XXI. Począwszy od I wojny światowej przez Europę przesuwają się wielkie masy ludzi wygnanych przez wojny, konflikty zbrojne, powstania, czystki etniczne ze swoich dotychczasowych siedzib. Czasami zmuszeni są oni do porzucenia miejsc zamieszkania przez głód, nędzę, brak możliwości zarobkowania, słowem - z przyczyn ekonomicznych. Kiedy indziej wyrywa ich z domostw, z małej osobistej ojczyzny gniew sąsiadów, czasem warunkowany światopoglądowo, czasem mający korzenie w uprzedzeniach rasowych bądź narodowych. Częstym i mniej znanym aż do XX wieku zjawiskiem są przesiedlenia wielkich grup społecznych, czasem całych narodów lub ich części w wyniku decyzji władz politycznych. Taki los spotkał, na przykład, Polaków z terenów Ukrainy i Litwy, a po zakończeniu działań wojennych Tatarów z Krymu. Niekiedy masową emigrację wywołuje obawa przed skutkami działań wojennych, kiedy to całe miasta i wsie rzucają się do mniej lub bardziej zorganizowanej ucieczki przed zbliżającymi się oddziałami wroga. Miało to miejsce w trakcie II wojny światowej, kiedy to na przykład cywilna ludność polska we wrześniu 1939 r. uciekała przed zbliżającą się nawałą hitlerowską i pod koniec II wojny, kiedy Niemcy z Prus Wschodnich i dzisiejszych tzw. ,ziem zachodnich" uciekali przed Armią Czerwoną. W wielu przypadkach migrację wywołują tak zwane ,czystki etniczne” lub obawa przed nimi. Takie zjawiska dało się zaobserwować w ostatnich latach na obszarze byłej Jugosławii. Powodem migracji bywały też przyczyny etniczne oraz rasowe, na przykład w odniesieniu do Ormian po I wojnie światowej i Żydów, w zasadzie począwszy od lat trzydziestych XX wieku. Charakterystycznym dla XX wieku zjawiskiem są migracje podyktowane obawami przed prześladowaniami politycznymi. Tego typu zdarzenia znane były już wcześniej, nawet w starożytności, ale nie przybierały charakteru masowe- 
go. Uchodźcami bywali nieliczni przywódcy polityczni, którzy właśnie na emigracji poszukiwali bądź spokojnego azylu, bądź możliwości zgromadzenia sił i stronników, aby podjąć ponownie walkę o realizację swoich idei. Większe grupy uchodźców pojawiały się w wyniku wojen religijnych i prześladowań z nimi związanych. Dotyczyło to na przykład: Braci Czeskich, francuskich Hugenotów, których potomkowie do dziś żyją w Niemczech, czy katolickich uciekinierów z protestanckiej Anglii. Dopiero wiek XIX przyniósł powszechne zainteresowanie polityką, a co za tym idzie zwiększenie liczby uchodźców politycznych. Byli wśród nich między innymi powstańcy listopadowi i styczniowi, rosyjscy przeciwnicy caratu itd. Wiek XX i początek bieżącego wieku przynosi eksplozję tego specyficznego zjawiska, jakim jest uchodźstwo polityczne. Uchodźcami byli: ajatollah Chomeini, a potem Reza Pahlavi, szach Iranu, bojownicy czeczeńscy, królowie obalonych monarchii i rewolucjoniści. Pojawia się przy tym ciekawe socjologicznie zjawisko ubierania się emigrantów zarobkowych w szaty uchodźców politycznych.

Społeczność międzynarodowa dość późno zareagowała na problem masowego uchodźstwa, które wystapiło po rewolucji październikowej i po rozpadzie Imperium Osmańskiego. Dopiero w 1921 r. Liga Narodów utworzyła Urząd Wysokiego Komisarza do spraw Uchodźców. Funkcję tę powierzono niezmiernie popularnemu w owych czasach, norweskiemu badaczowi polarnemu, dr. Fridtjöfowi Nansenowi, który jako pierwszy zwrócił uwagę na zjawisko uchodźców. Problem statusu uchodźców początkowo regulowało porozumienie genewskie z 5 lipca 1922 r. odnoszące się do uchodźców rosyjskich, których wyposażono w tak zwane paszporty nansenowskie, później porozumienie w sprawie uchodźców rosyjskich i armeńskich z 30 czerwca 1928 r. i oznaczone tą samą datą porozumienie w sprawie innej kategorii uchodźców. Po śmierci Nansena powołano Nansenowskie Biuro do spraw Uchodźców. 28 października 1933 r. czternaście państw, w tym także Polska, przyjęło Konwencję dotyczącą międzynarodowego statusu uchodźców, która ograniczała możliwość wydalenia i przymusowej repatriacji. Po dojściu Hitlera do władzy Liga Narodów została zmuszona do utworzenia urzędu Wysokiego Komisarza do spraw Uchodźców Politycznych z Niemiec. Konwencję regulującą status tych uchodźców przyjęto 20 lutego 1938 r., a wkrótce potem, w lipcu tegoż roku, na konferencji w Evian powołano Międzynarodowy Komitet do spraw Uchodźców, który miał objąć pomocą uciekinierów z Niemiec, Austrii i Sudetów. W kwietniu 1943 r. na konferencji na Bermudach rozszerzono działalność Komitetu na uchodźców z innych kra- 
jów. Siedzibą wspomnianego Komitetu jest Londyn. Komitet nie zajmuje się uchodźcami, którymi opiekuje się ich własne państwo lub Organizacja Narodów Zjednoczonych do spraw Pomocy i Odbudowy (UNRRA). Działalność tej organizacji i jej struktura była wielokrotnie opisywana, dlatego nie wypada jej w tym miejscu przypominać. Powołana 9 listopada 1943 r. na konferencji 44 delegatów państw i rządów toczących wojnę z państwami Osi pomagać miała obywatelom państw alianckich oraz obywatelom państw nieprzyjacielskich prześladowanych przez hitlerowców. Organizacja ta pomagała repatriacji osób wywiezionych przez nazistów z ojczyzny, udzielając im wsparcia finansowego. Nie potrafiła natomiast rozwiązać problemów osób wywiezionych, które ze względów politycznych nie decydowały się na powrót do ojczyzny ${ }^{1}$. Po zakończeniu wojny na pierwszej sesji Zgromadzenia Ogólnego ONZ powołano Międzynarodową Organizację do spraw Uchodźców (IRO - International Refugee Organization) Miała ona funkcjonować początkowo tylko przez trzy lata w praktyce jednak istniała do grudnia 1951 r., zajmując się nie tyle repatriacjami, co przesiedleniami ${ }^{2}$.

Zakończenie II wojny światowej nie zlikwidowało jednak samo przez się problemu uchodźców. Wypadki polityczne wyrzucały z dotychczasowych siedzib coraz to nowe grupy ludzi. W 1948 r., chcąc rozwiązać problem arabskich uciekinierów z Palestyny, utworzono organizację pod nazwą Pomoc Narodów Zjednoczonych dla Uchodźców z Palestyny, a wkrótce potem, 1 stycznia 1951 r., urząd Wysokiego Komisarza Narodów Zjednoczonych do spraw Uchodźców (UNHCR) z siedzibą w Gene$w_{i}^{3}$. Podstawą prawną działania tej ostatniej organizacji jest Konwencja dotycząca statusu uchodźców sporządzona w Genewie 28 lipca $1951 \mathrm{r}^{4}$

${ }^{1}$ G. Goodwin-Gil, The Refugees in International Law, Oxford 1998, wyd. II, s. 47; S. Angenendt, Asylum and Migration Policies in the European Union, Bonn 1999; M. Cutt, J. Boutrom, Uchodźcy świata 2000: 50 lat pomocy humanitarnej, Warszawa 2000, passim; A. Richmond, Socjological Theories of International Migration. The Case of Refugees, ,Journal of International Socjological Association” 1998, t. 36, nr 2.

2 D. Joly, C. Nettzeton, H. Poulton, Refugees: Asylum in Europa, London 1992, s. 51 i n.; A. Bernstein, M. Weiner, Migration and Refugees Policies: an Overview, London-New York 1999, passim.

${ }^{3}$ A. Florczak, Uchodźcy, w: Encyklopedia politologii, t. 5, Stosunki Międzynarodowe, Kraków 2002, s. 377 i n.; także Uchodźcy w Polsce, Toruń 2003, s. 12 i n.

${ }^{4}$ Dz. U. 1991, Nr 119, poz. 515, ratyfikując konwencję Polska zastrzegła, że nie będzie się uważała za związaną postanowieniami jej art. 24 ust. 2, dotyczącego odszkodowania za śmierć uchodźcy w wyniku pracy lub choroby zawodowej. 
i uzupełniający ją Protokół dotyczący statusu uchodźców, sporządzony w Nowym Jorku 31 stycznia 1967 r. $^{5}$

Oczywiście, wspomniane akty prawne nie rozwiązują w całości problemu, z jakim przychodzi zmagać się zarówno organizacjom międzynarodowym, jak i agendom poszczególnych państw usiłującym sprostać wyzwaniom, jakie niesie ta kwestia. Jedną z prób wytyczenia nowych rozwiązań jest tzw. Deklaracja Haska w sprawie przyszłości polityki uchodźczej i migracyjnej. Dokument ten został opracowany z inicjatywy holenderskiego oddziału Stowarzyszenia dla Rozwoju Międzynarodowego „w celu twórczej analizy przyszłości polityki uchodźczej i migracyjnej".

Stowarzyszenie dla Rozwoju Międzynarodowego (SID) powołano do życia w 1957 r. i jest, praktycznie rzecz biorąc, zupełnie nieznaną w Polsce organizacją pozarządową zrzeszającą zarówno osoby fizyczne, jak i różnorodne struktury społeczne. Stawia ono sobie za cel promowanie sprawiedliwości społecznej i popieranie demokratyzacji oraz ułatwienie dialogu, a także upowszechnianie wiedzy o świecie. Głównym jego zadaniem jest, jak głosi, wspieranie na wszystkich poziomach: lokalnych, narodowych i globalnych ,innowacyjnego rozwoju” i szukanie rozwiązań takich, jak bieda czy dyskryminacja z uwagi na płeć. Deklaruje ono także chęć wspierania inicjatyw stawiających sobie za cel działanie na rzecz sprawiedliwości społecznej, promowanie dialogu, zrozumienia i współpracy na poziomie społecznym i ekonomicznym. Stowarzyszenie dla Rozwoju Międzynarodowego skupia ponad 3000 członków indywidualnych z 125 państw oraz 55 członków instytucjonalnych. Posiada 65 oddziałów zgrupowanych w 5 regionach, to jest: w Europie, Ameryce, Afryce, Azji i na Pacyfiku. Współpracuje z ponad setką stowarzyszeń i organizacji, a także z licznymi uniwersytetami, uczonymi, ekspertami i parlamentarzystami ${ }^{6}$.

W listopadzie 1999 r. Holenderski Oddział Stowarzyszenia dla Rozwoju Międzynarodowego rozpoczął realizację obliczonego na trzy lata projektu dotyczącego przyszłości azylu i migracji. W założeniu projekt ten miał być niezależną inicjatywą mającą stymulować politykę i praktykę w tych właśnie dziedzinach. Odbyły się w Hadze w 2000 r. i 2001 r. seminaria realizujące jego założenia: cztery robocze oraz dodatkowo trzy

5 Dz. U. 1991, Nr 119, poz. 517.

6 Por.: www.sidint.org z 28 czerwca 2004 r. Society for International Development. 
seminaria poświęcone aspektom zdrowotnym, gospodarczym i demograficzno-ekonomicznym migracji. Podsumowaniem debat seminariów była sesja specjalna, która odbyła się 14 i 15 września 2001 r. w Hadze. Podjęto wtedy decyzję o opracowaniu dokumentu końcowego i wyłoniono grupę „strategii i przygotowania projektu”. Grupa ta odbyła dwa spotkania, w wyniku których zredagowana została Deklaracja Haska. Dokument gotów był jesienią 2002 r. i 22 listopada tegoż roku przedstawiono go w Hadze Sekretarzowi Generalnemu Narodów Zjednoczonych Kofi Annanowi ${ }^{7}$.

W preambule Deklaracji wyrażono przekonanie, iż sprawa uchodźców i emigrantów ma ogromne znaczenie dla społeczności międzynarodowej, dla pokojowej współpracy różnych państw, stabilności i bezpieczeństwa ekonomicznego, mimo odmienności natury, charakteru i bodźców tych przemieszczeń. Zdaniem twórców Deklaracji, „troska o obydwa zjawiska powinna być umiejscowiona w kontekście ekonomicznej i politycznej globalizacji wraz z wszystkimi ich możliwościami dla większego rozwoju ludzkości i pomyślności z jednej strony, tak aby uniknąć z drugiej strony wyobcowania, osłabienia, zubożenia i polaryzacji"». W preambule podkreślono, że migracja jest normalnym zjawiskiem, które może mieć pozytywny wkład w rozwój ekonomiczny i socjalny, wzbogacając kulturę różnych społeczeństw i czyniąc ją bardziej różnorodną. Czytając te deklaracje, nie sposób oprzeć się wrażeniu, że stanowią one zbiór niewątpliwie szczytnych, ale nie do końca przemyślanych frazesów, haseł i ogólników. Nie sposób zaprzeczyć, że migracja leży w interesie wielu wysoko rozwiniętych społeczeństw, jednak trudno podzielić pogląd, aby w każdym przypadku zbawienne i pożyteczne dla tych społeczeństw było zetknięcie się z innymi kulturami i zwyczajami. Przykład Francji, trudności, jakie przeżywa to państwo $\mathrm{w}$ zetknięciu $\mathrm{z}$ fundamentalizmem islamskim potomków byłych emigrantów z państw arabskich, wydaje się tu wysoce

7 W tworzeniu Deklaracji Haskiej brało udział, jak stwierdzają jej twórcy, ponad 500 osób z różnych stron świata, legitymujących się różnym doświadczeniem i przygotowaniem. W poszczególnych seminariach uczestniczyło od 40 do 45 osób, w obradach specjalnej sesji 190 osób. Około 25\% uczestników pochodziło z Holandii, 25\% z Afryki, Azji, Bliskiego Wschodu i Ameryki Łacińskiej, 25\%z Europy i Ameryki Północnej, pozostałe $25 \%$ to przedstawiciele różnych organizacji międzynarodowych. Jednym z uczestników seminarium i członkiem ,grupy strategii i przygotowania projektu” był prof. dr hab. Roman Wieruszewski z Instytutu Nauk Prawnych PAN.

${ }^{8}$ Autor dziękuje w tym miejscu p. mgr Katarzynie Degórskiej z Poznańskiego Centrum Praw Człowieka PAN za udostępnienie polskiego tłumaczenia tekstu Deklaracji, przeznaczonego do publikacji przez Biuro UNHCR w Warszawie. 
znamienny. Jednym z dość popularnych w naukach społecznych mitów jest wywodzące się z nurtu marksistowskiego przekonanie o potrzebie unifikacji kulturalnej przyszłego globalnego społeczeństwa. Objawem jej miałoby być, jak przewidywał J. Stalin, wykształcenie się jednego dla całej ludzkości języka ${ }^{9}$. Dość podobna w istocie rzeczy jest, obecnie nieco zmarginalizowana amerykańska koncepcja „tygla narodowego" ${ }^{\text {10. Jest }}$ rzeczą paradoksalną, że obie wspomniane wyżej koncepcje mimo różnych źródeł w istocie rzeczy zmierzają do tego samego celu o charakterze nacjonalistycznym. Według wywodzącego się z Rosji rozwiązania marksistowskiego, istniała potrzeba unifikacji kulturalnej narodów ZSRR wokół kultury rosyjskiej. Natomiast amerykańska koncepcja tygla, w istocie rzeczy, zmierzała do zasymilowania kulturalnego emigrantów przybywających do USA na podstawach angloprotestanckich ${ }^{11}$. Wypada zauważyć, że ekspansywność cywilizacji amerykańskiej - z tego terenu wywodzi się większość programów komputerowych, popularnych przebojów muzycznych, chętnie oglądanych filmów, poczytnych, chociaż nie zawsze najwyższego lotu, powieści - powoduje, że językiem dominującym w całym praktycznie świecie, swoistą „lingua franca” stał się angielski. Jego nie-

9 J. Stalin, W sprawie marksizmu w językoznawstwie, Warszawa 1950; tenże, Kwestia narodowa a leninizm, „Nowe Drogi” 1949, nr 6(18), s. 3-18. W artykule tym stwierdzono: „w miarę kształtowania się jednej światowej gospodarki socjalistycznej [...] zacznie kształtować się coś w rodzaju wspólnego języka, albowiem dopiero na tym etapie narody odczują konieczność posiadania jednego wspólnego języka międzynarodowego obok własnych języków narodowych [...]. Na następnym etapie [...] kiedy narody przekonają się w praktyce o wyższości wspólnego języka nad językami narodowymi - różnice i języki narodowe zaczną obumierać, ustępując miejsca wspólnemu dla wszystkich językowi światowemu".

10 N. Glazer, D. P. Moynikau, Beyond the Melting Pot: The Negroes, Puerto Ricans, Jews, Italians and Irish of New York City, New York 1970; M. L. Hansen, The Immigrant in American History, Washington 1940; E. Abbott (red.), Immigration: Selected Documents and Cases, New York 1924; B. Miller Solomon, Ancestors and Immigrants, New York 1956. Por. także A. Kapiszewski, Asymilacja i konflikt. Z problematyki stosunków etnicznych w Stanach Zjednoczonych Ameryki, Kraków 1984; tenże, Ideologia i teoria procesów asymilacji w USA. Problemy pluralizmu w latach osiemdziesiatych, „Przegląd Polonijny” 1981, z. 4, s. 5-15; tenże, Ideologia i teoria procesów asymilacji $w$ USA. Szkic problemu, tamże, 1981, z. 1, s. 5-24; tenże, Ideologie i teorie procesów asymilacji w USA. Ideologie i teorie pluralistyczne, tamże, z. 3, s. $14-35$.

11 Por. niezwykle ciekawe rozwiązania F. Znanieckiego o przenikaniu kultur. F. Znaniecki, Współczesne narody, Warszawa 1990, s. 208-225 oraz tegoż, Ludzie teraźniejsi a cywilizacja przyszłości, Warszawa 2001, s. 15-20, 49-58. 
znajomość praktycznie uniemożliwia funkcjonowanie w płaszczyźnie kultury i techniki. Tak więc wyróżnikiem kulturalnym staje się w większości społeczeństw religia, co trafnie przewidział nie tylko S. Huntington, lecz także A. Toynbee, F. Konieczny i inni ${ }^{12}$. Warto podkreślić, że ten stan rzeczy sprzyja fundamentalizmowi muzułmańskiemu, gdyż islam, będący religią zarówno państwa, jak i prawa w modlitwie, wymaga znajomości arabskiego.

Zgodzić się jednak należy z twórcami Deklaracji Haskiej co do tego, że świat dość biernie przygląda się sytuacji emigrantów i uchodźców bezbronnych wobec naruszania ich praw człowieka, poddanych prześladowaniu i brutalnemu traktowaniu. Słusznie zwrócono także uwagę na to, że uchodźcy i emigranci nie mogą w sposób należyty korzystać z ochrony międzynarodowej. Zauważono także, że ten stan rzeczy powoduje nadużywanie instytucji azylu.

Wszystkie te konstatacje prowadzą twórców Deklaracji do wniosku, iż konieczne jest pogodzenie dalekosiężnych interesów państw i społeczeństw z aspiracjami i potrzebami uczestników migracji. Społeczność międzynarodowa winna dążyć do ograniczenia zjawiska uchodźstwa, zapewniając wszystkim prawo i możliwość pozostania we własnym kraju, zapobiegając konfliktom i rozwiązując istotne spory. Ma ona jednak także obowiązek otoczenia uchodźców opieką, zgodnie z zasadami praw człowieka.

Tekst preambuły Deklaracji otwiera jej zasadniczą treść, na którą składają się: Zasady i Komentarz. Autorzy Deklaracji nie wyjaśniają wzajemnego związku tych dwóch części. Wydaje się to zaś dość istotne, gdyż w części Zasady nie ograniczono się jedynie do wymieniania ich, lecz także rozwinięto i skomentowano treść tych zasad. Część zatytułowana Komentarz w istocie rzeczy jest więc wyjaśnieniem do wcześniejszego komentarza zawartego w części Zasady. Tego typu redakcja dokumentu wydaje się wysoce chybiona i budzić musi, z punktu widzenia jasności legislacyjnej, głęboki sprzeciw prawnika, nawet przy założeniu, że Deklaracja to akt o charakterze politycznym, a nie normatywnym. Zwraca także uwagę sloganowość i ogólnikowość treści zawartych w obu częściach, które są prezentacją prawd ogólnie znanych i dość powszechnie akcepto-

12 A. J. Toynbee, Studium historii, Warszawa 2000, s. 556-557; S. P. Huntington, Zderzenie cywilizacji, Kraków 1935, s. 67-103, 174-226; F. Konieczny, O wielości cywilizacji, Kraków 1935, s. 153-155, 265-272, 309. Zob. także J. Sobczak, Zmierzch cywilizacji, Poznań 2002. 
wanych, jak i bezkarnie, w razie potrzeby, łamanych bądź zwyczajnie obchodzonych. Twórcy Deklaracji wyraźnie balansowali między potrzebą zachowania poprawności politycznej, szlachetnym współczuciem dla uchodźców i imigrantów, a obawą przed narażeniem się państwom, społecznościom i szeroko pojętej opinii publicznej. Stąd tekst Deklaracji jawi się odbiorcy jako „napuszony”, wysoce nieprecyzyjny traktat socjologiczny o ambicjach politycznych. W jego treści autorzy z dużą nonszalancją posługują się terminami, których nie starają się zdefiniować, nie bacząc na ich wieloznaczność i na to, że wywołują one spory i wątpliwości, powodując w praktyce poważne perturbacje. Trudno sądzić, aby tego typu dokument mógł odegrać poważniejszą rolę, aby obudził z letargu i zmusił do konstruktywnego działania rządy, urzędy i instytucje. Dlatego też nie sposób się dziwić, że przeszedł on prawie bez echa, a jego znajomość nawet wśród zainteresowanych jest więcej niż nikła. Jednak akt ten, mimo całej swojej banalności, odniósł się do wielu istotnych w praktyce problemów i dlatego godny jest analizy.

Deklaracja w pierwszej części formułuje 21 zasad, nie precyzując zreszta, co rozumie pod pojęciem zasady, a mianowicie: 1) odpowiedzialność państw, 2) skupienie na nowym dialogu, 3) regionalne podejście, 4) zarządzanie migracją, 5) mobilność i bezpieczeństwo, 6) uregulowana migracja, 7) nieuregulowana migracja, 8) ochrona uchodźców i azyl, 9) osoby wewnętrznie przesiedlone, 10) migracja i rozwój, 11) konflikt i zapobieganie konfliktom, 12) odbudowa skutków konfliktu, 13) nacisk na potencjały, 14) integracja i włączenie do społeczeństwa, 15) uczestnictwo i obowiązki, 16) uchodźstwo i migracja kobiet, 17) dzieci i rodziny, 18) rola sektora gospodarczego, 19) przywództwo, edukacja i informacja, 20) realizacja prawa, 21) formy instytucjonalne. W istocie rzeczy owe zasady to tylko wybrane kwestie spośród tych, które przychodzi rozwiązywać, dotykając problematyki uchodźców i migrantów.

Twórcy Deklaracji, z dużą dozą słuszności, konstatują powszechnie znaną prawdę historyczna, że migracja i zjawisko uchodźstwa nie jest niczym nowym i ma głębokie korzenie historyczne. Dodajmy - od czasów starożytnych. Uchodźcami byli przecież między innymi: Klejstenes, Temistokles, Alkibiades, Hannibal, Tyberiusz. Zdaniem autorów Deklaracji, ruchy migracyjne są jednym z ważniejszych skutków globalizacji i wynikają z bezprecedensowego przemieszczania się ludności w wielu częściach świata. U podłoża migracji leży poważna ekonomiczna, polityczna i socjalna niesprawiedliwość. Wymuszone przesiedlenie - a więc zjawisko uchodźstwa [przyp. mój J.S.] - jest konsekwencją braku stabilności 
w wielu regionach świata oraz łamania praw człowieka, fundamentalnych wolności i międzynarodowego prawa humanitarnego, i to często na masową skalę. W Deklaracji podkreślono, iż wyzwania wywołane przez ruchy migrantów, uchodźców, osób poszukujących azylu i innych przesiedleńców wymagają międzynarodowej reakcji, gdyż polityka i praktyka jednego państwa dotycząca ruchów populacyjnych z konieczności oddziałuje na inne państwa i regiony. Decydujące znaczenie ma odpowiedzialność państw pochodzenia, które winny się zająć przyczynami wymuszonych przemieszczeń i przepływów populacji, zarówno wtedy, gdy wiążą się z poszanowaniem praw człowieka, jak i reformami ekonomicznymi czy tworzeniem miejsc pracy. Państwa powinny dążyć do tego, aby nikt $\mathrm{z}$ ich obywateli nie musiał emigrować w celu przetrwania, mają też obowiązek przyjąć i zintegrować powracających obywateli. Sformułowania te porażają czytelnika bezmiarem politycznej naiwności. Twórcy Deklaracji jakby nie zauważali, że apele o reformy ekonomiczne kierowane do rządów ubogich krajów są, delikatnie rzecz ujmując, śmieszne. Nie ma bowiem państwa, które nie chciałoby być zasobne ekonomicznie, a przekształcenia gospodarcze nie dochodzą do skutku nie z racji braku przekonania o ich potrzebie, lecz z powodu braku środków, możliwości i warunków ich przeprowadzenia. W ostatecznym rozrachunku to rządy państw bogatych muszą rozważyć, czy chcą traktować inne kraje jako źródło bogactw naturalnych, rezerwuar siły roboczej i ewentualnie składowisko odpadków, czy też zależy im na tym, aby rozwijały się i bogaciły. Nikt jednak nie będzie chętnie dzielił się z ubogimi swoim statusem materialnym, chyba że zauważy w tym własny interes. O istnieniu takiej przesłanki mogłaby przekonywać Deklaracja, niestety - zamiast tego ogranicza się do formułowania pustych haseł i ogólnikowych frazesów.

Punktem wyjścia dla przyszłej globalnej polityki uchodźczej winien być, zdaniem twórców Deklaracji, wspólny interes wszystkich uczestników, a więc uchodźców, migrantów, społeczeństw obywatelskich, podmiotów ekonomicznych i rządów. Tego wspólnego interesu Deklaracja nie potrafi jednak zdefiniować. Wydaje się, iż, ujmując rzecz globalnie, takiego wspólnego interesu zwyczajnie nie ma. Każdy uchodźca i emigrant ma bowiem interes w znalezieniu schronienia i pracy. Państwa przyjmujące mają jednak interes w zatrudnieniu wysoko kwalifikowanych fachowców lub pracowników, którzy podejmują się ciężkich niewdzięcznych robót, których nie chcą wykonywać obywatele. Udzielając schronienia, państwa przyjmujące także dość często nie kierują się względami altruistycznymi, lecz mają na względzie korzyści polityczne o cha- 
rakterze doraźnym (na przykład: przyjmując uchodźców państwo nader często liczy na to, iż w przyszłości, po zmianie ekipy rządzącej, stanowić będą oni grupę ludzi przyjaznych krajowi, z którego gościny korzystali) lub długofalowymi (na przykład: w celu stworzenia w opinii publicznej określonego wizerunku). Paradoksalnie, rachuby te często obracają się przeciwko tym, którzy się nimi kierowali. Tak się stało, na przykład, w USA z uchodźcami z Kuby, we Francji z emigrantami z Algieru, w Holandii z uchodźcami rekrutującymi się $\mathrm{z}$ aparatu administracyjnego byłych kolonii ${ }^{13}$.

Niewątpliwie mają rację twórcy Deklaracji, kiedy twierdzą, że centrum dialogu między stronami (uczestnikami) globalnej polityki migracyjnej winny być organizacje humanitarne i organizacje praw człowieka oraz takie wyspecjalizowane agendy, jak Wysoki Komisarz Narodów Zjednoczonych do spraw Uchodźców (UNHCR) czy (mniej w Polsce znana) Międzynarodowa Organizacja do spraw Migracji (IOM). Z drugiej jednak strony w Deklaracji podkreślono, że dążąc do uporządkowania problemu uchodźstwa i migracji, konieczne jest zbudowanie w każdym z państw nowej polityki w tym względzie. Polityka ta musi z jednej strony służyć uzasadnionym narodowym interesom, z drugiej zaś - spełniać uniwersalne standardy międzynarodowych praw człowieka, międzynarodowego prawa humanitarnego i prawa uchodźczego. W Deklaracji stwierdzono, że dotychczas podstawa odpowiedzialność za politykę uchodźczą i migracyjną spoczywa na suwerennych państwach, w przyszłości jednak zasada solidarności, której dokument bliżej nie definiuje, wymagać będzie, by większą rolę w tej płaszczyźnie odgrywały struktury regionalne i międzynarodowe ${ }^{14}$. Przy okazji zauważono, iż poza wymienionymi, tak-

13 Por. w tych kwestiach oraz w sprawie polityki etnicznej m.in.: M. Cahen, Ethnicié politique. Pour une lecture réaliste de l'identité, Paris 1993; S. Chacker, Berbères aujourd'hui, Paris-Montréal 1998; G. Kepel, Les musulmans dans la societé française, Paris 1988; D. Schnapper, La France de l'intégration. Sociologie de la nation en 1990, Paris 1991; W. Żelazny, Asymilacja muzulmanów przez naród francuski, „Przegląd Religioznawczy” 2001, nr 2; tenże, Francja wobec mniejszości narodowych. Etniczność, etnopolityka, etnosocjologia, Tyczyn 2000 passim. Zob. także: R. Dahrendorf, Kilka prawd o emigracji, „Gazeta Wyborcza” 19-20 października 2002; A. Besançon, Drzwi zbyt szeroko otwarte, „Gazeta Wyborcza” 15-16 grudnia 2001.

14 Do takich struktur zasady Deklaracji zaliczają: Konsultacje ds. Uchodźców, Osób Przesiedlonych i Migrantów Krajów Azji i Pacyfiku (APC), Ekonomiczna Współpraca Krajów Azji i Pacyfiku (APEC), Stowarzyszenie Narodów Azji Południowo-Wschodniej (ASEAN), Wspólnota Niepodległych Państw (CIS), Środko- 
satywnie oficjalnymi, regionalnymi i podregionalnymi strukturami istnieje ogromny, twórczy potencjał w nieoficjalnych i nowych sieciach lub platformach dla rozwoju międzynarodowej i regionalnej współpracy dotyczącej spraw uchodźców i migrantów ${ }^{15}$.

Deklaracja akcentuje, że zgodnie z zasadą wolnego przepływu ludności, migranci mają prawo opuszczenia państwa pochodzenia, jednak ich możność zgodnego z prawem wjazdu do innego państwa musi być, z natury rzeczy, nadzorowana i regulowana przez ustawodawstwo państw przyjmujących. Na tych ostatnich państwach ciąży odpowiedzialność zrównoważenia praw i interesów migrantów z interesami obywateli. W omawianym akcie stwierdzono, że zarząd migracją musi być jawny i musi stwarzać możliwości uczestniczenia w nim, nie zadeklarowano jednak komu, bo chyba mimo wszystko nie zainteresowanym migracją. Zarząd ten winien mieścić się $\mathrm{w}$ granicach wskazanych w prawie międzynarodowym. Tworzący politykę migracyjną mają jednak konsultować się i powiadamiać o jej założeniach zarówno społeczności przyjmujące, jak i samych migrantów. Racjonalna strategia migracyjna musi brać pod uwagę potrzeby krajów, z których pochodzą migranci, krajów tranzytowych oraz krajów przeznaczenia, a także aspiracje samych migrantów. Winna ona szanować

woeuropejskie Porozumienie o Wolnym Handlu (CEFTA), Wspólny Rynek dla Wschodniej i Południowej Afryki (COMESA), Rada Europy, Grupa Deklaracji z Dakaru, Wspólnota Gospodarcza Państw Afryki Zachodniej (ECOWAS), Europejskie Stowarzyszenie Wolnego Handlu (EFTA), Unia Europejska (EU), Południowoamerykański Proces - Lima, Proces Manilski, Wspólny Rynek Południa (MERCOSUR czy COMISEC obejmujący Argentynę, Brazylię Paragwaj i Urugwaj), Południowoafrykański Dialog dotyczący Migracji (MIDSA), Północnoamerykańskie Porozumienie o Wolnym Handlu (NAFTA), Nowe Partnerstwo dla Rozwoju Afryki (NEPAD), Organizacja Bezpieczeństwa i Współpracy w Europie (OSCE), Puebla Process, Wspólnota Rozwoju Południowej Afryki (SADC) czy Południowoazjatyckie Stowarzyszenie Współpracy Regionalnej (SAARC). Jednocześnie odnotowano, że Międzynarodowa Organizacja ds. Migracji (IOM) rozwinęła innowacyjny program „Migracja dla Rozwoju w Afryce" (MIDA) mający na celu wzmocnienie udziału emigrantów W rozwoju państw pochodzenia.

15 Do tego typu struktur zaliczono takie jak: Grupa Deklaracji z Bangkoku, Inicjatywa Berneńska, Międzyrządowe Konsultacje dotyczące Polityki Azylowej, Uchodźczej i Migracyjnej w Europie, Północnej Ameryce i Australii (IGC), Międzynarodowe Centrum ds. Rozwoju Polityki Migracyjnej (ICMPD - „Proces Budapeszteński”), Międzynarodowy Program Polityki Migracyjnej (IMP - który zawiera Fundusz Populacyjny Narodów Zjednoczonych UNFPA, Szkoleniowy i Badawczy Instytut Narodów Zjednoczonych UNITA, Międzynarodową Organizację ds. Migracji IOM i Międzynarodową Organizację Pracy ILO) i należący do IOM dialog Polityki Migracyjnej. 
zaangażowanie i wkład migrantów w życie kraju przyjmującego, a także demograficzne, ekonomiczne, socjalne i kulturalne potrzeby społeczeństwa. Zarząd migracją jest, zdaniem twórców Deklaracji, skomplikowanym procesem, który wychodzi poza instrumenty karania i kontroli. U jego podstaw powinno leżeć uznanie faktu, iż migracja jest normalnym zjawiskiem życiowym tak dla jednostek, jak i rodzin, społeczeństw i państw.

Zdaniem twórców Deklaracji, ruchy ludnościowe wywoływały w przeszłości, i nadal wywołują, obawy dotyczące bezpieczeństwa. Podkreślają oni, że międzynarodowe wydarzenia natury przestępczej - pod którym to terminem rozumieja, jak się wydaje, terroryzm, rozpowszechnianie narkotyków i handel „żywym towarem” - mogą mieć i mają negatywny wpływ na publiczne postrzeganie szukających azylu i migrantów. Mogą zaistnieć także poważne napięcia społeczne związane z ruchami uchodźczymi i migracyjnymi. W sytuacji zagrożenia zewnętrznego dochodzi, według Deklaracji, do polaryzacji poglądów wpływowych grup społecznych. Rodzi to ryzyko pojawienia się nacisków na nieszanowanie standardów praw człowieka oraz objawienia się nietolerancji, ksenofobii, rasizmu. W Deklaracji przyznano, że zapewnienie bezpieczeństwa jest wręcz obowiązkiem każdego państwa, nie tylko w stosunku do własnych obywateli, lecz także wobec wszystkich, którzy znajdują się na jego terytorium. Nie do zaakceptowania jest jednak to, aby takie środki bezpieczeństwa ograniczały dostęp do azylu i szkodziły zaakceptowanym standardom ochrony uchodźców i migrantów.

Według Deklaracji, spójne i uporządkowane programy migracyjne mają kluczowe znaczenie dla zjawiska migracji. Państwa potrzebują stworzenia narodowych lub międzynarodowych zasad polityki, wskazujących na ich interesy $\mathrm{i}$ intencje w tej sferze. Takie zasady umocniłyby zaufanie publiczne i zwiększyłyby gotowość państw do reagowania w przypadkach kryzysów o charakterze humanitarnym. Transparentne rozwiązania wyjaśniłyby prawa i obowiązki migrantów, przyczyniając się do skanalizowania migracji i uczynienia tego zjawiska przewidywalnym. Zredukowałyby one, jak głosi Deklaracja, napięcia i koszty nielegalnej migracji i pomogły złamać zorganizowany handel ludźmi i ich ,przemyt”.

Analizując te stwierdzenia, nie sposób oprzeć się wrażeniu, iż twórcy Deklaracji ulegli częstemu wśród nieprawników przekonaniu, że norma prawna sama przez się może cokolwiek zmienić w postawach społecznych i jest władna w sposób dowolny kształtować rzeczywistość. Wydaje się, że Deklaracja zupełnie nie chce dostrzec gospodarczych i politycz- 
nych aspektów zjawiska emigracji. Mas uciekinierów chroniących się przed śmiercią, gwałtem, prześladowaniami, fali nędzarzy szukających pracy czy rzesz ludzi dążących do poprawy swojego bytu nie zatrzymają najbardziej transparentne zasady, najszczytniejsze hasła.

W myśl Deklaracji, nieuregulowana migracja jest bardzo często niebezpieczna dla samych migrantów, gdyż nie zapewnia im należytej ochrony prawnej, wywołując częstokroć także destabilizujące skutki dla państw pochodzenia, tranzytu i przeznaczenia. Nielegalni migranci przenoszą się nielegalnie, poruszają się bez stosownych dokumentów, narażeni na niebezpieczeństwa z powodu metod przemieszczania. $\mathrm{Ci}$, którzy wjadą na teren jakiegoś państwa nielegalnie, ale w poszukiwaniu azylu, powinni pamiętać, że Konwencja z 1951 r. dotycząca statusu uchodźców jednoznacznie zapewnia, że uchodźcy nie będą karani za ich niezgodny z prawem wjazd - przypominają twórcy Deklaracji ${ }^{16}$. W Deklaracji stwierdzono, że w interesie migrantów, jak i wszelkich zainteresowanych państw, jest to, aby międzynarodowa społeczność podążyła w kierunku bardziej uporządkowanej, legalnej migracji, co winno być możliwe do osiagnięcia przez międzypaństwową współpracę zniechęcającą, zapobiegającą nieuregulowanej migracji. Jednocześnie powrót do domu osób, którym odmówiono prawa azylu bądź legalnego pobytu w państwie, w którym chcieli mieszkać i pracować, musi być szybki, zaplanowany i ludzki ${ }^{17}$.

W treści Deklaracji stwierdzono, że polityka, jaką prowadzą państwa zmierzające do uregulowania systemów migracyjnych, nie może w żadnym wypadku pogarszać praw osób poszukujących azylu i uchodźców. Podkreślano także, że uchodźcy muszą uzyskać możliwość przejazdu przez terytoria różnych państw, aż znajdą się na obszarach, gdzie będą mieli zapewnione bezpieczeństwo i ochronę. Zauważono nawet, iż konieczna jest współpraca państw w celu organizowania bezpiecznych dróg

16 Konwencja Genewska dotycząca statusu uchodźców, sporządzona w Genewie 28 lipca 1951 r. (Dz. U. 1991, Nr 119, poz. 515 i 516); por. także Protokół Nowojorski dotyczący statusu uchodźców sporządzony w Nowym Jorku 31 stycznia 1967 r. (Dz. U. 1991, Nr 119, poz. 517 i 518). Powstanie Protokołu było konieczne, zważywszy iż Konwencja Genewska z 28 lipca 1951 r. obejmowała tylko osoby, które stały się uchodźcami na skutek zdarzeń sprzed 1 stycznia 1951 r. Tak więc powołanie się w tekście Deklaracji jedynie na wspomnianą Konwencję jest mało ścisłe i wręcz anachroniczne.

17 Dramatycznie trudna sytuacja uchodźców i azylantów bezskutecznie starających się o legalizację swojego pobytu w państwie, w którym znaleźli tymczasowe schronienie, stała się kanwą wielu powieści i opowiadań. Ciągle jeszcze najbardziej przejmująca jest książka Ericha Marii Remarque'a Łuk triumfalny. 
ucieczki dla uchodźców. W Deklaracji przypomniano, że w 1993 r. Światowa Konferencja Praw Człowieka w Wiedniu potwierdziła, że wszyscy mają prawo zarówno poszukiwania i uzyskiwania w innych państwach azylu przed prześladowaniami, jak i prawo powrotu do własnego kraju. Jednocześnie nadmieniono, że Ministerialne Spotkanie Państw w grudniu 2001 r. w sprawie Konwencji Genewskiej z 1951 r. dotyczącej statusu uchodźców w Genewie, nastąpiło po roku intensywnych badań środków ochrony uchodźców w ramach UNHCR-owskiego procesu „Globalnych Konsultacji”. Spotkanie to zakończyło się przyjęciem przez wiele rządów zobowiązań wyznaczonych przez Konwencję z 1951 r. w kwestii statusu uchodźców. Jednym z osiągnięć Globalnych Konsultacji było, jak skonstatowano w Deklaracji, powołanie Grupy Działania w sprawie Azylu i Migracji (AGAMI), która służyć miała między innymi poprawieniu współpracy między Biurem Wysokiego Komisarza Narodów Zjednoczonych do spraw Uchodźców (UNHCR) a Międzynarodową Organizacją do spraw Migracji (IOM).

Przypomnienie tych niewątpliwie ważnych działań i przedsięwzięć jest bardzo ważne, ale godne raczej studium naukowego niż dokumentu o charakterze polityczno-prawnym. Samo przez się nie wnosi także nic nowego do istoty sprawy. Trudno jednak powstrzymać cierpkie uwagi, kiedy okazuje się, że dla poprawienia współpracy między dwiema agendami o charakterze międzynarodowym powołuje się trzecią. Od tego typu działań los uchodźców i azylantów na pewno się nie poprawi. Zgodzić się jednak, oczywiście, trzeba ze stwierdzeniem zawartym w zasadach Deklaracji, iż dwa priorytetowe wyzwania dla międzynarodowej społeczności to: rozszerzenie ochrony uchodźców poprzez prowadzenie w życie zasad międzynarodowych praw człowieka, prawa humanitarnego i uchodźczego oraz odpowiadanie, w sposób wyczerpujący, „na potrzebę trwałych rozwiązań poprzez dobrowolną repatriację, lokalną integrację w państwach pierwszego azylu lub przesiedlenia do trzecich państw”. Zgodzić się też wypada z twórcami Deklaracji co do tego, że polityczne, finansowe i humanitarne koszty braku trwałych rozwiązań problemów uchodźców są znacznie większe od wprowadzenia proponowanych uregulowań.

Deklaracja podjęła także problem osób „wewnętrznie przesiedlonych”, tak zwanych IDPsów ${ }^{18}$, stwierdzając, że jest ich obecnie co najmniej

18 IDPs - Internally Displacet Persons. Prawa IDPsów zostały zebrane w Zasadach Przewodnich Narodów Zjednoczonych dotyczących wewnętrznego przesiedlenia. 
25000 000, z czego większość to kobiety i dzieci, a poziom ich ochrony jest zupełnie niewystarczający, natomiast problemy, z którymi się oni borykają, są pod wieloma względami takie same, jak uchodźców. Podstawową różnicą między IDP-sami a uchodźcami jest to, że ci pierwsi nie przekroczyli granicy państwowej i, formalnie rzecz biorąc, pozostają pod jurysdykcją własnego państwa. Twórcy Deklaracji podkreślili, że problemem jest to, iż w stosunku do osób „wewnętrznie przesiedlonych” nie ma jeszcze jasnego międzynarodowego mandatu upoważniającego do ich ochrony. Jednak, mimo że niespecjalnie dotyczą ich międzynarodowe konwencje, chroni IDP-sów międzynarodowe prawo humanitarne i prawa człowieka.

W Deklaracji z dużą dozą słuszności stwierdzono, że jedną z głównych przyczyn migracji są stale pogłębiające się ekonomiczne dysproporcje między poszczególnymi państwami, a także w ramach samych państw. Skonstatowano także, że ostatnio studia demograficzne ujawniają poważny wzrost liczby ludzi biednych borykających się z trudnymi warunkami bytowania. Sytuacja ta jest jednym z powodów migracji. Jednocześnie proces globalizacji rodzi nowe zapotrzebowania na rynku pracy, który poszukuje wysoko wykwalifikowanych pracowników. Rodzi to zjawisko tak zwanego „drenażu mózgów” i migrację fachowców z państw ubogich do wysokorozwiniętych. Pochodną tego stanu jest przekazywanie przez nich rodzinom w kraju pochodzenia znaczących sum. Jednak „drenaż mózgów" nie jest w szerszej perspektywie, według twórców Deklaracji, zjawiskiem pozytywnym i trzeba mu przeciwdziałać międzynarodową pomoca, stypendiami, szkoleniami i programami edukacyjnymi. Wszystkie te środki mają zmierzać do wykreowania takiego środowiska ekonomicznego i socjalnego, które zatrzyma fachowców w kraju przeznaczenia.

Powyższe stwierdzenia rażą bezkrytycyzmem i infantylnością. Jest bowiem jasne, że różnic gospodarczych nie da się łatwo zniwelować, a programy edukacyjne przyczynią się do wykreowania znacznej liczby osób wykwalifikowanych, którzy nie znajdując dla siebie w ojczyźnie odpowiedniej pracy, ulegną frustracji, pogłębiając niezadowolenie społeczne lub też prędzej zdecydują się na emigrację.

W optyce Deklaracji, głównymi przyczynami ruchów migracyjnych są wojny domowe, konflikty zbrojne, skrajna przemoc, okupacja i inwazja. Charakterystyczne jest to, że wiele konfliktów trwa bardzo długo i nie znajduje rozwiązania przez lata. Natura ich zmienia się, gdyż ostatnimi czasy zaczynają dominować konflikty wewnętrzne, których ofiarami są w pierwszym rzędzie cywile. „Ubocznym” efektem tych konfliktów są 
migracje. Twórcy Deklaracji podkreślają konieczność zapobiegania konfliktom zbrojnym, dopatrując się szczególnych zadań i obowiązków, w tym po stronie Organizacji Narodów Zjednoczonych i Międzynarodowego Trybunału Karnego ${ }^{19}$. Zdaniem Deklaracji, równie ważna jest likwidacja skutków konfliktu, odbudowa instytucji i gospodarki, ustanowienie rządów prawa, co stworzy warunki do powrotu ofiar konfliktu, osób „wewnętrznie przesiedlonych”, jednak nadmiernie pospieszny powrót uchodźców z krajów udzielających azylu może pogłębić napięcia społeczne, jeśli nie zostanie przywrócony trwały pokój i nie zostanie zapewniona stabilizacja.

W treści Deklaracji podkreślono, że uchodźcy i migranci posiadają umiejętności, wiedzę, doświadczenie i charakteryzują się silną motywacją do osiagnięcia wyższego standardu życia. Tego potencjału polityki migracyjne poszczególnych państw nie chcą brać pod uwagę, akcentując jedynie ograniczenia i przeszkody. Restrykcje pozbawiają ludzi, przeciwko którym są stosowane, w ostatecznym rozrachunku, motywacji, powodując, iż ludzie ci nie rozwijają swoich możliwości, co ujemnie odbija się na nich samych i na społeczeństwach przyjmujących ich państw. Według Deklaracji, należy doceniać potencjał uchodźców i migrantów, którzy przyczyniają się do społecznego i ekonomicznego rozwoju krajów przyjmujących, dodatkowo wspierając jeszcze finansowo rodziny w krajach pochodzenia. Kraje przyjmujące powinny zapewnić uchodźcom i emigrantom dostęp nie tylko do rynku pracy, lecz także do edukacji, opieki zdrowotnej i innych publicznych świadczeń. Powinny ich także zachęcać do prowadzenia życia zaspokajającego ich potrzeby.

W Deklaracji podkreślono potrzebę wczesnej integracji migrantów opartej na równym traktowaniu i zakazie dyskryminacji. Praca, szkolenie, łączenie rodzin, edukacja dla dzieci i dostęp do służby zdrowia i innych publicznych świadczeń mają kluczowe znaczenie dla powodzenia integracji. W proces ten powinna być także zaangażowana społeczność lokalna, a emigranci winni znać i rozumieć jej potrzeby. Tak więc integracja

19 Deklaracja zwraca uwagę na fakt, że ofiarami konfliktów są nader często dzieci, częstokroć wykorzystywane jako żołnierze. Odnotowuje raport Gracii Machal z 1996 r. „Wpływ konfliktów zbrojnych na dzieci” podkreślając, że Protokół Dodatkowy z 2000 r. do Konwencji o prawach dziecka odnoszący się do zaangażowania dzieci w konfliktach zbrojnych winien być przyjęty przez wszystkie państwa na świecie. Polska ratyfikowała wspomnianą Konwencję (Dz. U. 1991, Nr 120, poz. 526), ale, jak dotychczas, nie przyjęła Protokołu Dodatkowego. 
jest procesem dwutorowym i wymaga zaangażowania tak samych uchodźców i migrantów, jak i ludności krajów przyjmujących, wśród której przyszło tym migrantom żyć i pracować. Twórcy Deklaracji zwracają uwagę na konieczność przeciwdziałania szczególnie groźnym w procesie integracji postawom populistycznym, rasistowskim i ksenofobicznym. Wymaga to współdziałania rządów, kościołów, liderów społecznych i politycznych, środków przekazu, organizacji kobiecych i instytucji egzekwujących prawo. Wszystkie te podmioty powinny zadbać o to, by w państwach przyjmujących migrantów funkcjonowało skuteczne, niedyskryminujące prawo. Także programy promujące integrację muszą być oparte na zasadzie niedyskryminacji. Sama zaś integracja nie oznacza asymilacji i winna opierać się na uznaniu wartości wielokulturowości. Wczesna integracja uchodźców i migrantów leży, według Deklaracji, w interesie wszystkich, a w szczególności przyjmującej społeczności. Nieudana może doprowadzić do marginalizacji, alienacji, dyskryminacji i izolacji. Ta ostatnia sytuacja przynosić może korzyści jedynie tym, którzy dążą do spotęgowania napięć społecznych, aby je wykorzystać dla swoich partykularnych, politycznych bądź ideologicznych. Zmiana tradycyjnego modelu migracji, spowodowana nowymi technologiami komunikacji i większą mobilnością ludzi, wymaga rozwinięcia bardziej elastycznego prawnego i socjalnego systemu integracji i reintegracji.

W Deklaracji silnie zaakcentowano, że zarówno uchodźcy, jak i migranci mają obowiązek przestrzegania prawa obowiązującego w kraju przyjmującym. Uchodźcy i migranci tworzą część rozwijającego się multikulturalnego krajobrazu społeczeństwa, które ich przyjmuje. Socjalne i ekonomiczne interesy uchodźców i migrantów coraz bardziej, w miarę upływu lat, zazębiają się z interesami miejscowej społeczności i dlatego powinny być wyrażane w postaci dialogu przybyszów z przyjmującym społeczeństwem. Wczesne i aktywne uczestnictwo uchodźców i migrantów w podejmowaniu decyzji dotyczących nie tylko ich sfery działania, lecz całej społeczności, w której funkcjonują, jawi się jako niezbędne. Dobrze prowadzony dialog z władzami i społeczeństwem gwarantuje obustronny szacunek i zrozumienie, poręczając stabilność społeczną. Twórcy Deklaracji konstatuja, iż w praktyce dialog ten jest wysoce niedostateczny, upatrując przyczyny tego stanu rzeczy w kulturalnych i komunikacyjnych barierach $\mathrm{z}$ jednej strony oraz w braku zainteresowania i obawie, iż może być on zbyt trudny z drugiej strony. Stwierdzają też, że bardzo często dialog i propozycja udziału w życiu społeczeństwa przychodzą zbyt późno lub pojawiają się jedynie w czasie kryzysu społecznego. Porażka 
w procesie dialogu prowadzi do: marginalizacji, alienacji, dyskryminacji, swoistego socjalnego apartheidu, niezdolności do korzystania z socjalnych i zdrowotnych usług w społeczeństwie przyjmującym. Celem dialogu winno być w pierwszym rzędzie zapewnienie pełnego zrozumienia przez wszystkie strony kompleksu uprawnień, odpowiedzialności, praw i obowiązków, poszanowanie różnic międzygrupowych i stworzenie zdrowej, społecznej i kulturowej spójności.

Nie sposób oprzeć się jednak wrażeniu, że tak postawione cele, niewątpliwie szczytne i godne pochwały, są jednak niemożliwe do zrealizowania. Twórcy Deklaracji zdają się nie brać pod uwagę dążenia części przybyszów do pełnej asymilacji i zatarcia śladów swojego pochodzenia. Objawia się to w zmianie nazwisk, czasem religii, przyjęciu obcych wzorów kulturowych. Na przeszkodzie tego typu postępowania stają czasami jedynie, co paradoksalne, cechy rasowe (kolor skóry).

Twórcy Deklaracji podkreślają także konieczność jak najszerszego uwzględnienia w polityce migracyjnej kobiet, które stanowią znaczny odsetek przybyszów ${ }^{20}$. Konieczne jest większe wykorzystanie ich potencjału intelektualnego i umiejętności zawodowych. Polityka migracyjna musi w większym stopniu uwzględniać ich potrzeby, przy czym zarówno państwo, jak i lokalne władze samorządowe powinny szczególnie starać się o to, aby ułatwić im zarówno integrację, jak i zachowanie tradycji kulturalnych ${ }^{21}$.

${ }^{20}$ Według szacunkowych i niepewnych danych, kobiety i dzieci stanowią $80 \%$ uchodźców i osób ,wewnętrznie przesiedlonych” (IDP-sów) i 40\% wszystkich innych migrantów. Por. Uchodźcy świata. 50 lat pomocy humanitarnej, UNHCR, s. 340-354; Przewodnik po międzynarodowym prawie azylowym, UNHCR, s. 30, 40-42, 63-64, $71-74$.

${ }^{21}$ W Deklaracji podkreślono szczególną rolę Konwencji w sprawie likwidacji wszelkich form dyskryminacji kobiet przyjętą przez Zgromadzenie Ogólne Narodów Zjednoczonych w Nowym Jorku z 18 grudnia 1979 r. Konwencja ta została ratyfikowana przez Polskę 18 lipca 1980 r. (Dz. U. 1982, Nr 10, poz. 71). Protokół Fakultatywny do tej Konwencji przyjęty przez Zgromadzenie Ogólne Narodów Zjednoczonych w Nowym Jorku 6 października 1999 r. został także ratyfikowany przez Polskę (Dz. U. 2003, Nr 41, poz. 343). Zapomina jednak o utworzonym na podstawie art. 17-tej Konwencji Komitecie do spraw Likwidacji Dyskryminacji Kobiet oraz o Oddziale Promocji Kobiet ONZ (Division for the Advancement of Women) z siedzibą w Nowym Jorku. Milczy też Deklaracja o innych ważnych aktach prawa międzynarodowego publicznego mających przeciwdziałać dyskryminacji kobiet, między innymi o ratyfikowanych przez Polskę: Konwencji międzynarodowej o zakazie pracy nocnej kobiet zatrudnionych w przemyśle, przyjętej w Brnie 26 września 1906 r. (Dz. U. 1922, 
Deklaracja nie zauważa jednak, że wśród przybyszów istnieją dwie grupy kobiet: większa - to osoby poświęcające się głównie prowadzeniu domu, żony i matki, wyjątkowo tylko podejmujące pracę zawodową oraz mniejsza - skupiająca młodsze, częstokroć bardzo wykształcone niewiasty. Niedostatecznie zaakcentowano także to, iż w społecznościach tradycyjnych, a z nich wywodzi się większość migrantów, właśnie kobiety stają najczęściej na straży tradycyjnych przyzwyczajeń obyczajowych i tradycji kulturowych.

Deklaracja podkreśla, że rozdzielenie rodziny jest częstą konsekwencją migracji i przemieszczeń. Fundamentalną normą jest zasada jedności rodziny, która musi być respektowana. Konieczne jest pozyskiwanie środków finansowych na odszukiwanie członków rodziny uchodźcy. Trzeba także zadbać o zaspokojenie potrzeb edukacyjnych dzieci migrantów ${ }^{22}$.

Twórcy Deklaracji zauważyli także, że prywatny sektor gospodarczy odgrywa coraz ważniejszą rolę międzynarodową, która znajduje odbicie

Nr 19, poz. 158); Międzynarodowym Porozumieniu dotyczącym zwalczania handlu żywym towarem, przyjętym w Paryżu 18 maja 1904 r., Międzynarodowej Konwencji dotyczącej handlu żywym towarem, przyjętej w Paryżu 4 maja 1910 (Dz. U. 1922, Nr 87, poz. 783); Międzynarodowej Konwencji o zwalczaniu handlu kobietami i dziećmi, przyjętej w Genewie 30 września 1921 r. (Dz. U. 1925, Nr 125, poz. 893); Konwencji o zwalczaniu handlu kobietami pełnoletnimi, przyjętej w Genewie 11 października 1933 r. (Dz. U. 1938, Nr 7, poz. 37); Konwencji w sprawie zwalczania handlu ludźmi i eksploatacji prostytucji, przyjętej w Lake Success 21 marca 1950 r. (Dz. U. 1952, $\mathrm{Nr} 41$, poz. 278); niezmiernie ważnej Konwencji o prawach politycznych kobiet, przyjętej w Nowym Jorku 31 marca 1953 r. (Dz. U. 1955, Nr 16, poz. 86); Konwencji (nr 100) dotyczącej jednakowego wynagrodzenia dla pracujących mężczyzn i kobiet za pracę jednakowej wartości, przyjętej w Genewie 29 czerwca 1951 r. (Dz. U. 1955, $\mathrm{Nr} 38$, poz. 238); Konwencji (nr 103) dotyczącej ochrony macierzyństwa (zrewidowanej w 1952 r.), przyjętej w Genewie 28 czerwca 1952 r. (Dz. U. 1976, Nr 16, poz. 99); Konwencji o obywatelstwie kobiet zamężnych, przyjętej w Nowym Jorku 20 lutego 1957 r. (Dz. U. 1959, Nr 56, poz. 334). Por. w tych kwestiach: R. Wieruszewski, Zasada równości i niedyskryminacji, w: Prawa człowieka. Model prawny, red. R. Wieruszewski, Wrocław-Warszawa-Kraków 1991, s. 75-96; tenże, Równość kobiet i mężczyzn w Polsce Ludowej, Poznań 1975, tam obszerniejsza literatura; Z. Dembińska, ONZ a prawa kobiet, w: ONZ a problemy wspótczesnego świata, Warszawa 1972; M. Wamdzel, Równe traktowanie mężczyzn i kobiet, Kraków 2003; I. Boruta, Równość kobiet $i$ mężczyzn w świetle prawa wspólnoty europejskiej, Łódź 1996.

${ }^{22}$ W Deklaracji podkreślono, że dobrą podstawą dla tych działań jest Konwencja o prawach dziecka, przyjęta przez Zgromadzenie Ogólne ONZ 20 listopada 1989 r. (Dz. U. 1991, Nr 120, poz. 526, zm.: Dz. U. 2000, Nr 2, poz. 11). Dodać jedynie wypada, że jest to najważniejszy $\mathrm{z}$ aktów chroniący prawa dziecka, ale nie jedyny. 
w nowych wymiarach jego odpowiedzialności społecznej. Na ludziach z prywatnego biznesu ciążą obowiązki poszanowania praw człowieka szczególnie w płaszczyźnie standardów prawa pracy i ochrony środowiska. Podkreślono, że muszą oni unikać sytuacji, w których ich działalność będzie podsycała konflikty. Wręcz przeciwnie mogą przyczyniać się do odbudowania po konfliktach socjalnej, ekonomicznej i kulturalnej infrastruktury, stymulować włączenie się do rynku pracy uchodźców i migrantów w krajach przyjmujących i w rezultacie wzmacniać procesy integracyjne $^{23}$.

Według Deklaracji, przyszłość dobrej polityki uchodźczej i migracyjnej zależy od właściwego wsparcia publicznego oraz od dobrych badań i informacji, bardziej niż od działań obronnych i pełnych obaw debat. Podniesiono, że obecnie uchodźcy i migranci wywołują sprzeczne reakcje: z jednej strony niepokój, niepewność, strach, obawę przed zagrożeniem tożsamości, z drugiej zaś ludzką solidarność, sympatię, współczucie i nadzieję na ekonomiczne i kulturowe wzbogacenie, które uchodźcy i migranci zawsze przynosili do kraju przyjmującego. Publiczna debata nad tym problemem bazuje jednak bardzo często na braku informacji. Bardzo negatywną rolę odgrywają też środki przekazu częstokroć umyślnie wprowadzające w błąd opinię publiczną. Brak też polityków, którzy byliby w stanie sprostać tym problemom. Niewystarczająca jest także prawna reakcja przeciwko dyskryminacji, rasizmowi i ksenofobii. Rolą mediów jest, jak zauważono w Deklaracji, unikanie stereotypowej prezentacji i przyczynianie się do stworzenia atmosfery gościnności i akceptacji uchodźców i migrantów. Wiele także zależy od ludzi młodych.

Skuteczne instrumenty praw człowieka, międzynarodowego prawa humanitarnego oraz prawa uchodźczego istnieją po to, aby chronić uchodźców i zmniejszać zasięg migracji ${ }^{24}$. Priorytetem na przyszłość jest zapew-

23 W Deklaracji podkreślono, że współcześnie funkcjonuje wiele inicjatyw mających na celu zwrócenie uwagi na społeczną rolę sektora gospodarczego w tym „Global Compact" Narodów Zjednoczonych. Podkomisja Narodów Zjednoczonych do spraw Promocji i Ochrony Praw Człowieka, Organizacja dla Ekonomicznej Współpracy i Rozwoju i Międzynarodowa Organizacja Pracy (ILO) opracowały w tym względzie specjalne wskazówki.

24 Podstawowe międzynarodowe instrumenty praw człowieka od czasu Powszechnej Deklaracji Praw Człowieka w 1948 r. to: Konwencja z 1949 r. dotycząca migracji dla zatrudnienia, Konwencja z 1951 r. dotycząca statusu uchodźców i jej Protokół Dodatkowy z 1967 r., Międzynarodowy Kodeks Praw (składający się z Powszechnej Deklaracji Praw Człowieka z 1948 r., Międzynarodowego Paktu Praw 
nienie ich efektywnej realizacji. Głównym zadaniem państw jest w tej sytuacji otwarta dyskusja nad trudnościami związanymi ze stosowaniem obowiązującego prawa i dążenie do wypełniania uzgodnionych standardów międzynarodowych. Konieczne jest dokonanie pełnej implementacji standardów międzynarodowych do obszaru prawa krajowego ${ }^{25}$.

Osobistych i Politycznych z 1966 r. oraz Międzynarodowego Paktu Praw Gospodarczych, Społecznych i Kulturalnych z 1966 r.) Międzynarodowa Konwencja w sprawie likwidacji wszelkich form dyskryminacji rasowej z 1965 r., Konwencja dotycząca migracji w niewłaściwych warunkach oraz popierania równości szans i traktowania pracowników migrujących z 1975 r. (ILO), Cztery Konwencje Genewskie z 1949 r. i dwa Protokoły Dodatkowe z 1977 r., Konwencja w sprawie likwidacji wszelkich form dyskryminacji kobiet z 1979 r., Konwencja w sprawie zakazu stosowania tortur oraz innego okrutnego, nieludzkiego lub poniżającego traktowania albo karania z 1984 r., Konwencja o prawach dziecka z 1989 r., Konwencja w sprawie ochrony praw wszystkich pracowników migrujących i członków ich rodzin i ponadto Traktat z 1999 r. przeciwko przemytowi ludzi oraz Konwencja Narodów Zjednoczonych z 2000 r. Międzynarodowej Przestępczości Zorganizowanej i jej Dodatkowych Protokołach przeciwko przemytowi migrantów drogą lądową, morską i powietrzną.

Podstawowe regionalne instrumenty praw człowieka to: Konwencja Organizacji Jedności Afrykańskiej z 1969 r. (OAU) dotycząca specyficznych aspektów uchodźstwa w Afryce, Afrykańska Karta Praw Człowieka i Ludów, Deklaracja z Bangkoku w sprawie nieuregulowanej migracji z 1999 r., Europejska Konwencja o Ochronie Praw Człowieka i Podstawowych Wolności z 1950 r., Konwencja z Dublina określająca odpowiedzialność państw za rozpatrywanie wniosków o azyl w państwach Wspólnot Europejskich z 1990 r., Deklaracja z Kartaginy w sprawie uchodźców oraz Amerykańska Konwencja Praw Człowieka z 1969 r. Dodatkowo: z 1996 r. Azjatycko-Afrykański Prawny Komitet Konsultacyjny (AALCC) przyjął niewiążące zasady dotyczące uchodźców. W dużej mierze przyjmuje on definicję Konwencji z $1951 \mathrm{r}$. dotyczącą statusu uchodźców i jej Protokoł z 1967 r., ale także traktuje o azylu i gwarantuje tymczasową ochronę. Zasady zostały rozszerzone, by objąć swym zakresem wspólną odpowiedzialność. Obecnie są one ponownie dyskutowane w ramach Konsultacji Azji i Pacyfiku w sprawie Uchodźców, Osób Przesiedlonych i Migrantów (APC). Rozpoczęły się w 1996 r. i dotyczą nie tylko uchodźców, ale także nieuregulowanej migracji. Na Bliskim Wschodzie, gdzie występuje ogromna liczba długotrwałych przypadków osób przesiedlonych, istnieje Arabska Karta Praw Człowieka, jednakże nie weszła ona jeszcze w życie. Wymienionym instrumentom towarzyszą międzynarodowe wskazówki i zasady, którymi są między innymi: Wiedeńska Deklaracja z 1993 r., Wnioski Komitetu Wykonawczego UNHCR, Standardy Narodów Zjednoczonych dotyczące Minimalnych Zasad Zatrzymania oraz Konstytucja Międzynarodowej Organizacji do spraw Migracji (IOM) z 1987 r.

${ }_{25}$ Implementacja składa się, według Deklaracji, z dwóch elementów: po pierwsze, ratyfikacji istniejących regionalnych i międzynarodowych instrumentów (oraz, kiedy jest to konieczne, inkorporacji do krajowych porządków prawnych) oraz po drugie, monitorowania państw przy wypełnianiu ich zobowiązań. Chodzi o monitorowanie 
Przechodząc do końcowego problemu form instytucjonalnych, w Deklaracji stwierdzono, że wiele takich form rozwiniętych w XX wieku w celu sprostania problemom uchodźców i migracji zestarzało się. Podkreślono, że w chwili obecnej wiele czasu i wysiłku wkłada się w usiłowanie skoordynowania działalności międzyrządowych organizacji z odpowiednimi agendami ONZ ${ }^{26}$. Konieczny wydaje się więc przegląd i uaktualnienie tych instytucji. W myśl Deklaracji, głośne błędy społeczności międzynarodowej w rozwiązywaniu kryzysowych problemów same przez się powodują niepokój i przyczyniają się do podważenia wiarygodności systemu Narodów Zjednoczonych. Odpowiedzialne międzynarodowe instytucje wymagają bardziej spójnej, niezawodnej i zasobniejszej bazy finansowej. Organy władz krajowych i międzyrządowe oraz pozarządowe organizacje muszą posiadać dobrze wyszkolony i zorganizowany personel. Odnowione ramy instytucjonalne przyczynią się, zdaniem twórców Deklaracji, do pozytywnego rozwoju ekonomicznego migrantów, zwiększenia ich pewności socjalnej, bezpieczeństwa, zapewnią opiekę zdrowotną i umożliwią rozwój kulturalny.

Przedstawiona w tym miejscu Deklaracja Haska niewątpliwie jest ważnym dokumentem wielokrotnie trafnie definiującym słabości polityki migracyjnej, i to zarówno na poziomie międzynarodowym, jak i krajowym. Akt ten daleki jest jednak od prawniczej ścisłości, zwięzłości i precyzyjności. Słabością jego jest sloganowość stwierdzeń i brak jasnych propozycji rozwiązania niewątpliwie nabrzmiałych problemów. Może stanowić co najwyżej zaczyn do poważniejszej dyskusji.

zobowiązań państw do Konwencji z 1951 r. dotyczącej statusu uchodźców (i Protokołu z 1967 r.) pod względem przestrzegania art. 35 tej konwencji. Implementacja krajowego i międzynarodowego prawa zależy nie tylko od formalnych mechanizmów ich wprowadzenia w życie, takich jak: policja, wymiar sprawiedliwości, wojsko i urzędnicy imigracyjni, ale także od czujności opinii publicznej, a w szczególności od organizacji społecznych. Pełna i uniwersalna implementacja, jak zauważono w Deklaracji, będzie nieuchronnie wymagała wspólnego międzynarodowego wysiłku, by sprawić, że dostępne będą właściwe środki i wiedza pomagające państwom realizować ich konwencyjne zobowiązania.

26 Uwagi te Deklaracja kieruje do: Biura UNHCR, Biura Wysokiego Komisarza Narodów Zjednoczonych do spraw Praw Człowieka (OHCHR), Funduszu Narodów Zjednoczonych na rzecz Dzieci (UNICEF), ILO, Agencji Narodów Zjednoczonych do spraw Pomocy Uchodźcom Palestyńskim na Bliskim Wschodzie (UNRWA) oraz, poza systemem Narodów Zjednoczonych, Międzynarodowego Komitetu Czerwonego Krzyża (ICRC) i Międzynarodowej Organizacji do spraw Migracji (IOM). 


\section{Summary}

The problem of fugitives, migrants and internally displaced persons constitutes one of the more important issues in internal politics of individual states as well as in international relations. An attempt to establish the principles and set directions for such a policy is expressed in the Hague Declaration, adopted in 2002 as motioned for by the Dutch local chapter of the Society for International Development (SID).

The paper presents and reviews the contents of the Declaration, which emphasizes the responsibility of states for the situation of refugees and migrants and the need to establish the principles of such a policy. It also refers to the problems of regulated and non-regulated migration, the issue of assimilation, integration, the law of migrants to return and the duties of state institutions, local governments, religious organizations and social institutions in the reception countries. The Declaration addresses political and economic reasons for migration and it emphasizes that the work of fugitives and migrants does not only bring benefits to them, but also to the reception countries and families in the homeland. The Declaration pays particular attention to children and female refugees and to the need for specific regulations in this respect. It refers to human rights while observing the inertia and lack of concepts of specialized international agencies. 